\title{
Antioxidative Constituents from the Twigs of Vitex rotundifolia
}

\author{
Dae Keun Kıм* \\ College of Pharmacy, Woosuk University, Jeonju 565-701, Republic of Korea
}

(Received August 10, 2009; Revised September 18, 2009; Accepted September 24, 2009)

\begin{abstract}
In the course of screening for antioxidant compounds by measuring the radical scavenging effect on DPPH (1,1-diphenyl- 2-picrylhydrazyl), a total extract of the twigs of Vitex rotundifolia (Verbenaceae) was found to show potent antioxidant activity. Subsequent activity-guided fractionation of the methanolic extract led to the isolation of three iridoid compounds, 10-O-vanilloylaucubin (1), 10-O-p-hydroxybenzoylaucubin (2) and aucubin (3), two C-glycoside flavones, vitexin (4) and orientin (5), and a quinic acid derivative, 3,4-di-O-caffeoylquinic acid (6). Their structures were elucidated by spectroscopic studies. Among them, compounds 5 and 6 showed the significant antioxidative effects on DPPH free radical scavenging test. In riboflavin-NBT-light and xanthine-NBT-xanthine oxidase systems, compounds 5 and 6 exhibited the formation of the blue formazan in a dose-dependent manner. Compounds 5 and 6 showed better superoxide quenching activities than vitamin $\mathrm{C}$.
\end{abstract}

Keywords: Vitex rotundifolia, Verbenaceae, Iridoid, Phenolic compounds, DPPH, Superoxide quenching activity

\section{INTRODUCTION}

Vitex rotundifolia L. fil. (Verbenaceae) is widely distributed in Asia including Korea, Japan and China, and its fruit has been used in folk medicine for cold, headache, migraine, sore eyes, night blindness and neuralgia (Kimura et al., 1996). Earlier investigation on the chemical constituents of $V$. rotundifolia dealt with sesquiterpenes, diterpenes, flavones, lignans, phenylpropanoids and iridoids in fruit of this plant (Ono et al., 1997, 1999, 2001, 2002; You et al., 1998; Okuyama et al., 1998; Ko et al., 2000; Yoshioka et al., 2004). But phytochemical and pharmacological studies of the twigs of this plant has not been performed yet.

In the course of searching for antioxidants from plants by measuring the radical scavenging effect on DPPH (1,1-diphenyl-2-picrylhydrazyl), a total extract of the twigs of $V$. rotundifolia was found to show potent antioxidant activity. Subsequent activity-guided fractionation of the methanolic extract led to the isolation of six compounds, 10-O-vanilloylaucubin (1), 10-O-p-hydroxybenzoylaucubin (2) and aucubin (3), two C-glycoside flavones, vitexin (4)

${ }^{*}$ Corresponding author

Tel: +82-63-290-1574 Fax: +82-63-290-1812

E-mail: dkkim@mail.woosuk.ac.kr and orientin (5), and a quinic acid derivative, 3,4-di-O-caffeoylquinic acid (6) from the active ethyl acetate fraction. Among them, compounds 5 and 6 showed the significant antioxidative effects on DPPH free radical scavenging test, and superoxide quenching activity tests. This paper deals with the isolation and structural characterization of these compounds and their scavenging activity of the stable DPPH free radical and superoxide quenching activity.

\section{MATERIALS AND METHODS}

\section{General experimental procedures}

NMR spectra were determined on a JEOL JMN-EX 400 spectrometer. Sephadex LH-20 was used for column chromatography (Pharmacia, 25-100 $\mu \mathrm{m}$ ). Prep-HPLC was carried out on a Jaigel GS310 column (Japan). TLC was carried out on Merck precoated silica gel $\mathrm{F}_{254}$ plates and silica gel for column chromatography was Kiesel gel 60 (230-400 mesh, Merck). Spots were detected under UV and by spraying with $10 \% \mathrm{H}_{2} \mathrm{SO}_{4}$ in ethanol followed by heating at $100-120^{\circ} \mathrm{C}$ for $3 \mathrm{~min}$. All other chemicals and solvents were of analytical grade and used without further purification. Ascorbic acid and BHA (butylated hydroxyanisole) were obtained from Sigma Chemical Co. 


\section{Plant materials}

The twigs of $V$. rotundifolia were collected in October 2006 at Taeahn, Chungnam, Korea, and identified by Jong Pil Lim, College of Pharmacy, Woosuk University. A voucher specimen was deposited in the herbarium of the College of Pharmacy, Woosuk University (WSU-06-022).

\section{Extraction and isolation}

The shade dried and powdered twigs of $V$. rotundifolia $(600 \mathrm{~g})$ was extracted three times with hot $\mathrm{MeOH}$, and then filtered. The extracts were combined and evaporated in vacuo at $40^{\circ} \mathrm{C}$. The resultant methanolic extract $(58 \mathrm{~g})$ was successively partitioned as methylene chloride, ethyl acetate, $n$-butanol and water soluble fractions. Each fraction was tested for the radical scavenging effect on DPPH (1,1-diphenyl-2-picrylhydrazyl). Among these fractions, the ethyl acetate soluble fraction $(7 \mathrm{~g})$ showed the most significant free radical scavenging effect on DPPH. This fraction was subjected to chromatography on a Sephadex $\mathrm{LH}-20$ column (MeOH only), and give five fractions (E1E5). Fraction E1 (3.5 g) was chromatographed on silica gel column chromatography $\left(\mathrm{CHCl}_{3}-\mathrm{MeOH}-\mathrm{H}_{2} \mathrm{O}, 40: 10: 1\right)$ as an eluent to give six subfractions (E11-E16). Subfraction E12 (260 mg) was further chromatographed on a silica gel Lobar A column $\left(\mathrm{CHCl}_{3}-\mathrm{MeOH}-\mathrm{H}_{2} \mathrm{O}, 3: 1: 1\right)$ and purified by a GS310 column $\mathrm{LH}-20(\mathrm{MeOH})$ to give compound 1 (41 $\mathrm{mg})$. Subfraction E14 (1.3 g) was crystallize with $\mathrm{MeOH}$ to give compound 2 (19 mg). Subfraction E15 (93 mg) was further chromatographed on a GS310 column (MeOH) to give compound 3 (10 mg) and 4 (9 mg). Fraction E3 (1.3 g) was chromatographed on silica gel column chromatography $\left(\mathrm{CHCl}_{3}-\mathrm{MeOH}-\mathrm{H}_{2} \mathrm{O}, 40: 10: 1\right)$ as an eluent to give five subfractions (E31-E35). Subfraction E32 (136 mg) was crystallize with $\mathrm{MeOH}$ to give compound $5(10 \mathrm{mg})$. Subfraction E35 $(70 \mathrm{mg})$ was purified on a GS310 column $(\mathrm{MeOH})$ to give compounds $6(20 \mathrm{mg})$.

\section{0-O-Vanilloylaucubin (1)}

White powder (MeOH), ${ }^{1} \mathrm{H}-\mathrm{NMR}\left(400 \mathrm{MHz}, \mathrm{CD}_{3} \mathrm{OD}\right) \delta$ : $7.61(1 \mathrm{H}, \mathrm{dd}, \mathrm{J}=8.4,1.6 \mathrm{~Hz}, \mathrm{H}-6$ "), $7.59(1 \mathrm{H}, \mathrm{d}, \mathrm{J}=1.6 \mathrm{~Hz}$, H-2"), 6.86 (1H, d, J=8.4 Hz, H-5"), 6.34 (1H, dd, J=6.0, 2.0 $\mathrm{Hz}, \mathrm{H}-3), 5.83(1 \mathrm{H}, \mathrm{s}, \mathrm{H}-7), 5.11(1 \mathrm{H}, \mathrm{dd}, \mathrm{J}=6.0,4.3 \mathrm{~Hz}$, $\mathrm{H}-4), 5.08(1 \mathrm{H}, \mathrm{d}, \mathrm{J}=15.5 \mathrm{~Hz}, \mathrm{Ha}-10), 5.03(1 \mathrm{H}, \mathrm{d}, J=7.2$ $\mathrm{Hz}, \mathrm{H}-1), 4.92(1 \mathrm{H}, \mathrm{d}, \mathrm{J}=15.5 \mathrm{~Hz}, \mathrm{Hb}-10), 4.70(1 \mathrm{H}, \mathrm{d}$, $\left.J=8.0 \mathrm{~Hz}, \mathrm{H}-1^{\prime}\right), 4.47(1 \mathrm{H}, \mathrm{m}, \mathrm{H}-6), 3.90\left(3 \mathrm{H}, \mathrm{s}, \mathrm{OCH}_{3}\right)$, $3.84(1 \mathrm{H}, \mathrm{dd}, \mathrm{J}=11.6,1.8 \mathrm{~Hz}, \mathrm{Ha}-6$ '), $3.66(1 \mathrm{H}, \mathrm{dd}, \mathrm{J}=11.6$, $6.1 \mathrm{~Hz}, \mathrm{Hb}-6$ '), 3.39 (1H, dd, J=8.8, 8.8 Hz, H-3'), $3.00(1 \mathrm{H}$, t-like, J=7.3 Hz, H-9), $2.71(1 \mathrm{H}, \mathrm{m}, \mathrm{H}-5) .{ }^{13} \mathrm{C}-\mathrm{NMR}(100$ $\left.\mathrm{MHz}, \mathrm{CD}_{3} \mathrm{OD}\right) \delta$ : Table I.
Table I. ${ }^{13} \mathrm{C}-\mathrm{NMR}$ spectral data of compounds $1-5$

\begin{tabular}{rrrrrr}
\hline C & \multicolumn{1}{c}{1} & \multicolumn{1}{c}{2} & \multicolumn{1}{c}{3} & \multicolumn{1}{c}{4} & \multicolumn{1}{c}{5} \\
\hline 1 & 97.8 & 98.0 & \multicolumn{1}{c}{97.7} & - & - \\
2 & \multicolumn{1}{c}{-} & \multicolumn{1}{c}{-} & \multicolumn{1}{c}{-} & 167.8 & 166.2 \\
3 & 141.7 & 141.7 & 141.6 & 104.1 & 103.9 \\
4 & 105.5 & 105.5 & 105.7 & 184.2 & 184.0 \\
5 & 46.2 & 46.3 & 46.2 & 162.3 & 162.0 \\
6 & 82.8 & 82.8 & 82.8 & 95.6 & 95.2 \\
7 & 132.5 & 132.4 & 130.2 & 164.6 & 164.9 \\
8 & 142.9 & 142.9 & 148.0 & 110.0 & 109.1 \\
9 & 48.5 & 48.5 & 47.9 & 158.8 & 158.7 \\
10 & 63.8 & 63.6 & 62.6 & 105.6 & 105.2 \\
$1^{\prime}$ & 100.2 & 100.2 & 99.9 & 122.5 & 123.5 \\
$2^{\prime}$ & 74.9 & 74.9 & 74.9 & 133.0 & 114.1 \\
$3^{\prime}$ & 78.0 & 77.9 & 77.9 & 116.5 & 147.0 \\
$4^{\prime}$ & 71.5 & 71.4 & 71.5 & 164.4 & 151.0 \\
$5^{\prime}$ & 78.2 & 78.2 & 78.2 & 116.5 & 116.8 \\
$6^{\prime}$ & 62.7 & 62.7 & 61.4 & 133.0 & 120.3 \\
$1^{\prime \prime}$ & 122.4 & 122.1 & & 75.0 & 75.3 \\
$2^{\prime \prime}$ & 113.6 & 132.9 & & 71.5 & 71.8 \\
$3^{\prime \prime}$ & 153.1 & 116.2 & & 81.1 & 80.1 \\
$4^{\prime \prime}$ & 148.8 & 163.6 & & 71.1 & 72.6 \\
$5^{\prime \prime}$ & 116.0 & 116.2 & & 82.9 & 82.6 \\
$6^{\prime \prime}$ & 125.2 & 132.9 & & 62.8 & 62.9 \\
$7^{\prime \prime}$ & 167.8 & 167.8 & & & \\
$\mathrm{OCH}_{3}$ & 56.5 & & & & \\
\hline $\mathrm{R}^{\prime \prime}$ & & & &
\end{tabular}

Recorded at $100 \mathrm{MHz}$ for ${ }^{13} \mathrm{C}-\mathrm{NMR}$ in $\mathrm{CD}_{3} \mathrm{OD}$.

\section{0-O-p-Hydroxybenzoylaucubin (2)}

White powder (MeOH), ${ }^{1} \mathrm{H}-\mathrm{NMR}\left(400 \mathrm{MHz}, \mathrm{CD}_{3} \mathrm{OD}\right) \delta$ : $7.82(2 \mathrm{H}, \mathrm{d}, \mathrm{J}=8.8 \mathrm{~Hz}, \mathrm{H}-2$ ", 6") $6.74(2 \mathrm{H}, \mathrm{d}, \mathrm{J}=8.8 \mathrm{~Hz}$, H-3", 5"), 6.24 (1H, dd, J=6.0, $2.0 \mathrm{~Hz}, \mathrm{H}-3), 5.73(1 \mathrm{H}, \mathrm{s}$, $\mathrm{H}-7), 5.03(1 \mathrm{H}, \mathrm{dd}, \mathrm{J}=6.0,4.3 \mathrm{~Hz}, \mathrm{H}-4), 4.99(1 \mathrm{H}, \mathrm{d}, \mathrm{J}=15.6$ $\mathrm{Hz}, \mathrm{Ha}-10), 4.89(1 \mathrm{H}, \mathrm{d}, J=7.6 \mathrm{~Hz}, \mathrm{H}-1), 4.80(1 \mathrm{H}, \mathrm{d}$, $J=15.6 \mathrm{~Hz}, \mathrm{Hb}-10), 4.60\left(1 \mathrm{H}, \mathrm{d}, J=8.0 \mathrm{~Hz}, \mathrm{H}-1^{\prime}\right), 4.38(1 \mathrm{H}$, m, H-6), $3.76(1 \mathrm{H}, \mathrm{dd}, J=11.6,1.8 \mathrm{~Hz}, \mathrm{Ha}-6$ ') $3.57(1 \mathrm{H}, \mathrm{dd}$, $J=11.6,6.1 \mathrm{~Hz}, \mathrm{Hb}-6$ '), $3.26(1 \mathrm{H}, \mathrm{dd}, \mathrm{J}=8.8,8.8 \mathrm{~Hz}, \mathrm{H}-3$ '), $2.89(1 \mathrm{H}, \mathrm{t}$-like, J=7.4 Hz, H-9), 2.61 (1H, m, H-5). ${ }^{13} \mathrm{C}-\mathrm{NMR}\left(100 \mathrm{MHz}, \mathrm{CD}_{3} \mathrm{OD}\right) \delta$ : Table I.

\section{Aucubin (3)}

White powder $(\mathrm{MeOH}),{ }^{1} \mathrm{H}-\mathrm{NMR}\left(400 \mathrm{MHz}, \mathrm{CD}_{3} \mathrm{OD}\right) \delta$ : $6.26(1 \mathrm{H}, \mathrm{dd}, \mathrm{J}=5.6,2.0 \mathrm{~Hz}, \mathrm{H}-3), 5.72(1 \mathrm{H}, \mathrm{s}, \mathrm{H}-7), 5.04$ $(1 \mathrm{H}, \mathrm{dd}, J=5.6,4.3 \mathrm{~Hz}, \mathrm{H}-4), 4.90(1 \mathrm{H}, \mathrm{d}, J=7.6 \mathrm{~Hz}, \mathrm{H}-1)$, $4.62\left(1 \mathrm{H}, \mathrm{d}, \mathrm{J}=8.0 \mathrm{~Hz}, \mathrm{H}-1^{\prime}\right), 4.39(1 \mathrm{H}, \mathrm{m}, \mathrm{H}-6), 4.29(1 \mathrm{H}, \mathrm{d}$, $J=15.2 \mathrm{~Hz}, \mathrm{Ha}-10), 4.12(1 \mathrm{H}, \mathrm{d}, \mathrm{J}=15.2 \mathrm{~Hz}, \mathrm{Hb}-10), 3.82$ (1H, dd, J=11.6, 1.8 Hz, Ha-6'), 3.65 (1H, dd, J=11.6, 6.1 $\mathrm{Hz}, \mathrm{Hb}-6$ '), 2.84 (1H, t-like, J=7.6 Hz, H-9), 2.61 (1H, m, $\mathrm{H}-5) .{ }^{13} \mathrm{C}-\mathrm{NMR}\left(100 \mathrm{MHz}, \mathrm{CD}_{3} \mathrm{OD}\right) \delta$ : Table I. 


\section{Vitexin (4)}

Yellow powder $(\mathrm{MeOH}),{ }^{1} \mathrm{H}-\mathrm{NMR}(400 \mathrm{MHz},) \delta: 7.93$ $\left(2 \mathrm{H}, \mathrm{d}, J=8.8 \mathrm{~Hz}, \mathrm{H}-2^{\prime}, 6^{\prime}\right), 6.83(1 \mathrm{H}, \mathrm{s}, \mathrm{H}-3), 6.81(2 \mathrm{H}, \mathrm{d}$, $\left.J=8.8 \mathrm{~Hz}, \mathrm{H}-3^{\prime}, 5^{\prime}\right), 6.41(1 \mathrm{H}, \mathrm{s}, \mathrm{H}-6), 4.67(1 \mathrm{H}, \mathrm{d}, \mathrm{J}=9.1 \mathrm{~Hz}$, $\mathrm{H}-1$ "). ${ }^{13} \mathrm{C}-\mathrm{NMR}\left(100 \mathrm{MHz}, \mathrm{CD}_{3} \mathrm{OD}\right) \delta$ : Table I.

\section{Orientin (5)}

Yellow powder $(\mathrm{MeOH}),{ }^{1} \mathrm{H}-\mathrm{NMR}\left(400 \mathrm{MHz}, \mathrm{CD}_{3} \mathrm{OD}\right) \delta$ : $7.33\left(1 \mathrm{H}, \mathrm{dd}, \mathrm{J}=8.8,2.0 \mathrm{~Hz}, \mathrm{H}-6^{\prime}\right), 7.32(1 \mathrm{H}, \mathrm{d}, J=2.0 \mathrm{~Hz}$, $\left.\mathrm{H}-2^{\prime}\right), 6.87\left(1 \mathrm{H}, \mathrm{d}, \mathrm{J}=8.8 \mathrm{~Hz}, \mathrm{H}-5^{\prime}\right), 6.50(1 \mathrm{H}, \mathrm{s}, \mathrm{H}-3), 6.44$ $(1 \mathrm{H}, \mathrm{s}, \mathrm{H}-6), 4.19(1 \mathrm{H}, \mathrm{d}, \mathrm{J}=7.2 \mathrm{~Hz}, \mathrm{H}-1$ ) $) .{ }^{13} \mathrm{C}-\mathrm{NMR}(100$ $\left.\mathrm{MHz}, \mathrm{CD}_{3} \mathrm{OD}\right) \delta$ : Table I.

\section{3,4-Di-O-caffeoylquinic acid (6)}

Yellow powder $(\mathrm{MeOH}),{ }^{1} \mathrm{H}-\mathrm{NMR}\left(400 \mathrm{MHz}, \mathrm{CD}_{3} \mathrm{OD}\right) \delta$ : $7.57(1 \mathrm{H}, \mathrm{d}, J=15.6 \mathrm{~Hz}, \mathrm{H}-3$ "), $7.51(1 \mathrm{H}, \mathrm{d}, J=15.6 \mathrm{~Hz}$, H-3'), $7.05(1 \mathrm{H}, \mathrm{d}, J=2.0 \mathrm{~Hz}, \mathrm{H}-5$ "), $7.01(1 \mathrm{H}, \mathrm{d}, J=2.0 \mathrm{~Hz}$, $\left.\mathrm{H}^{-5}\right), 6.92\left(1 \mathrm{H}, \mathrm{dd}, \mathrm{J}=8.0,2.0 \mathrm{~Hz}, \mathrm{H}-9^{\prime \prime}\right), 6.87(1 \mathrm{H}, \mathrm{dd}$, $\left.J=8.0,2.0 \mathrm{~Hz}, \mathrm{H}-9^{\prime}\right), 6.76\left(1 \mathrm{H}, \mathrm{d}, J=8.0 \mathrm{~Hz}, \mathrm{H}-8^{\prime \prime}\right), 6.75(1 \mathrm{H}$, d, J=8.0 Hz, H-8'), $6.29(1 \mathrm{H}, \mathrm{d}, J=15.6 \mathrm{~Hz}, \mathrm{H}-2$ '), $6.24(1 \mathrm{H}$, d, J=15.6 Hz, H-2'), $5.62(1 \mathrm{H}, \mathrm{m}, \mathrm{H}-3), 5.18(1 \mathrm{H}, \mathrm{m}, \mathrm{H}-4)$, $4.15(2 \mathrm{H}, \mathrm{m}, \mathrm{H}-5) .{ }^{13} \mathrm{C}-\mathrm{NMR}\left(100 \mathrm{MHz}, \mathrm{CD}_{3} \mathrm{OD}\right) \delta: 181.8$ (COO), 168.5 (C-1"), 168.4 (C-1'), 149.6 (C-7'), 149.5 (C-7"), 147.4 (C-3'), 147.2 (C-3"), 146.8 (C-6'), 146.7 (C-6"), 127.8 (C-4'), 127.7 (C-4"), 123.2 (C-9'), 123.1 (C-9"), 116.5 (C-8'), 116.4 (C-8”), 115.3 (C-5'), 115.2 (C-5”), 115.1 (C-2'), 114.9 (C-2"), 75.6 (C-1), 74.6 (C-4), 70.0 (C-5), 67.6 (C-3), 38.09 (C-2) and 38.05 (C-6).

\section{DPPH radical scavenging effect}

Ethanol solutions of test samples at various concentrations $(0.1-100 \mu \mathrm{g} / \mathrm{ml})$ were added to a solution of DPPH in methanol $(0.2 \mathrm{mM})$ in 96 well plates. After storing these mixtures for 30 minutes at room temperature, the remaining amounts of DPPH were determined by colorimetry at $520 \mathrm{~nm}$ on a microplate reader (Yoshida et al., 1989). And the radical scavenging activity of each compound was expressed by the ratio of the lowering of the DPPH solution in the absence of compounds. The mean values were obtained from triplicate experiments.

\section{Riboflavin and superoxide quenching activity (Choi et al., 2001)}

Superoxide quenching activities of test samples were measured photochemically, using an assay system consisting of methionine, riboflavin, and nitrobluetetrazolium (NBT) (Ginnopolitis and Ries, 1977). The reaction mixture was composed of $0.13 \mu \mathrm{M}$ riboflavin, $13 \mathrm{mM}$ methionine, $75 \mu \mathrm{M}$ NBT, $0.1 \mathrm{mM}$ EDTA, PBS buffer (pH 7.4), and various concentrations of test samples. The sample was ran- domly placed in a light storage box and replaced randomly every $5 \mathrm{~min}$ for $15 \mathrm{~min}$. The temperature within the light storage box was $20 \pm 1^{\circ} \mathrm{C}$ during the light illumination. The light intensity at the sample level was 5,500 lux. During the light illumination, NBT was reduced to blue formazane formation was measured by the absorbance at $560 \mathrm{~nm}$. The inhibition of blue formazane formation was taken as superoxide quenching activity.

\section{Xanthine and superoxide scavenging assay}

Superoxide radicals were generated by xanthine/xanthine oxidase and measured by previously reported method (Thuong et al., 2007). In briefly, test samples were mixed with $20 \mathrm{mM}$ phosphate buffer (PH7.8) containing $0.48 \mathrm{mM} \mathrm{NBT}$ and $1.6 \mathrm{mM}$ xanthine. After $5 \mathrm{~min}$, xanthine oxidase $(0.05 \mathrm{U} / \mathrm{ml}) 100 \mu \mathrm{l}$ was added. The absorbance of reaction mixture was read at $570 \mathrm{~nm}$ after $30 \mathrm{~min}$ incubation at $37^{\circ} \mathrm{C}$. Superoxide radical scavenging activity was expressed by the degree of NBT reduction of a test group in comparison to that of control.

\section{RESULTS AND DISCUSSION}

In the course of our screening for antioxidative components from natural plants, the ethyl acetate soluble fraction of methanolic extract of the twigs of $V$. rotundifolia was found to show scavenging activity on DPPH radical (Fig. 2). Subsequent activity-guided fractionation of the ethyl acetate soluble fraction led to the isolation of three iridoid compounds, two C-glycoside flavones, and a quinic acid derivative (Fig. 1).

Compounds 1-3 have similar patterns in their NMR spectra. Compound 1 was obtained as an amorphous powder from $\mathrm{MeOH}$. The ${ }^{1} \mathrm{H}-\mathrm{NMR}$ spectrum of 1 showed two double doublet peaks at $\delta 6.34(1 \mathrm{H}, \mathrm{dd}, J=6.0,2.0 \mathrm{~Hz})$ and $5.11(1 \mathrm{H}, \mathrm{dd}, \mathrm{J}=6.0,4.3 \mathrm{~Hz})$, which were assigned to protons at $\mathrm{C}-3$ and $\mathrm{C}-4$, a singlet peak at $\delta 5.83$ (C-7), and a methoxy signal at $\delta 3.90(3 \mathrm{H}, \mathrm{s})$. And also, the ${ }^{1} \mathrm{H}-\mathrm{NMR}$ spectrum of 1 showed the typical pattern of a coupling group of 1,3,4-trisubstituted benzene ring at $\delta 7.61(1 \mathrm{H}$, dd, $J=8.4,1.6 \mathrm{~Hz}, \mathrm{H}-6$ "), $7.59(1 \mathrm{H}, \mathrm{d}, J=1.6 \mathrm{~Hz}, \mathrm{H}-2$ ") and $6.86\left(1 \mathrm{H}, \mathrm{d}, \mathrm{J}=8.4 \mathrm{~Hz}, \mathrm{H}-5\right.$ "). In the ${ }^{13} \mathrm{C}-\mathrm{NMR}$ spectrum of 1,22 carbon signals were observed, which included a carbonyl group at $\delta 167.8$, ten aromatic or olefinic carbons at $\delta$ $141.7,105.5,132.5,142.9,122.4,113.6,153.1,148.8$, 116.0 and 125.2, six sugar carbons at $\delta 100.2,74.9,78.0$, $71.5,78.2$ and 62.7 , and a methoy group at $\delta 56.3$. From these results, compound 1 was deduced to be an iridoid glycoside bearing a 1,3,4-trisubstituted aromatic ring. The structure of 1 was determined to be 10-O-vanilloylaucubin 


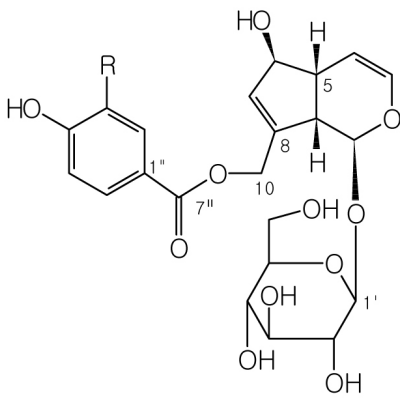

$1 \mathrm{R}=\mathrm{OCH}_{3}$ $2 \mathrm{R}=\mathrm{H}$<smiles></smiles>

$$
4 \mathrm{R}=\mathrm{H}
$$

$5 \mathrm{R}=\mathrm{OH}$<smiles>O=C(/C=C/c1ccc(O)c(O)c1)OC1C[C@](O)(C(=O)O)CC[C@@H]1OC(=O)/C=C/c1ccc(O)c(O)c1</smiles>

6

Fig. 1. Structures of compounds 1-6 isolated from Vitex rotundifolia.

(VR-1) on the basis of the above evidences, together with a comparison of the above data with those published in the literature (Ono et al., 1997).

The NMR spectrum of 2 was very similar to that of 1 . The main differences were chemical shifts of aromatic ring and the absence of methoxy group. The ${ }^{1} \mathrm{H}-\mathrm{NMR}$ spectrum of 2 showed two ortho-coupled doublets each of two protons with a J value of $8.8 \mathrm{~Hz}$ at $\delta 7.82(2 \mathrm{H}, \mathrm{d}, \mathrm{H}-2 ", 6$ ") and $6.74(2 \mathrm{H}, \mathrm{d}, \mathrm{H}-3$ " , 5"), indicating the presence of a 1,4-disubstituted aromatic ring. From these results, compound 2 was deduced to be an iridoid glycoside bearing a 1,4-disubstituted aromatic ring. The structure of 2 was deter-

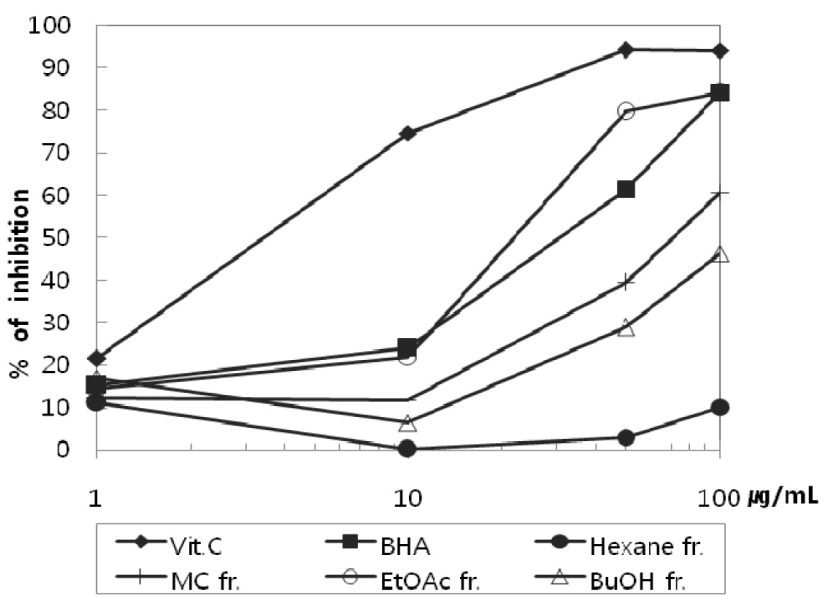

Fig. 2. Radical scavenging effects on DPPH radical of the fractions from the twigs of $V$. rotundifolia.

mined to be 10-O-p-hydroybenzoylaucubin (agnuside) on the basis of the above evidences, together with a comparison of the above data with those published in the literature (Ono et al., 1997). The NMR spectrum of 3 was similar to that of 2 except for the absence of aromatic group. According to this result, compound 3 was deduced to be a simple iridoid glycoside. The structure of 3 was determined to be aucubin on the basis of the above evidence, together with a comparison of the above result with those published in the literature (El-Naggar and Beal, 1980).

Compounds 4 and 5 have similar patterns in their NMR spectra. Compounds 4 and 5 were obtained as an amorphous powder from $\mathrm{MeOH}$. The ${ }^{1} \mathrm{H}-\mathrm{NMR}$ spectrum of 4 showed two ortho-coupled doublets each of two protons with a $J$ value of $8.8 \mathrm{~Hz}$ at $\delta 7.93\left(2 \mathrm{H}, \mathrm{d}, \mathrm{H}-2^{\prime}, 6^{\prime}\right)$ and 6.81 $\left(2 \mathrm{H}, \mathrm{d}, \mathrm{H}-3^{\prime}, 5^{\prime}\right)$, indicating the presence of a 1,4-disubstituted aromatic ring, and two singlet protons at $\delta 6.83$ and 6.41 (each $1 \mathrm{H}, \mathrm{s}$ ) were observed in olefinic area. In the ${ }^{13} \mathrm{C}-\mathrm{NMR}$ spectrum of 4 , twenty one carbon signals were observed, which included a carbonyl carbon $(\delta$ 184.2, $C-4)$, and six oxygenated aliphatic carbons $(\delta 82.9,81.1$, $75.0,71.5,71.1$, and 62.8). From these results, compound 4 was deduced to be a flavonoid glycoside bearing a 1,4-disubstituted aromatic B-ring. The structure of 4 was determined to be vitexin on the basis of the above evidences, together with a comparison of the above data with those published in the literature (Cheng et al., 2007). The NMR spectrum of 5 was very similar to that of 4 . The main differences were chemical shifts of aromatic B-ring. The ${ }^{1} \mathrm{H}-\mathrm{NMR}$ spectrum of 5 showed the typical pattern of a coupling group of 1,3,4-trisubstituted benzene ring at $\delta 7.33$ $\left(1 \mathrm{H}, \mathrm{dd}, J=8.4,1.6 \mathrm{~Hz}, \mathrm{H}-6^{\prime}\right), 7.32\left(1 \mathrm{H}, \mathrm{d}, J=1.6 \mathrm{~Hz}, \mathrm{H}-2^{\prime}\right)$. In the ${ }^{13} \mathrm{C}$-NMR spectrum, twenty one carbon signals were 
observed, which included a carbonyl group at $\delta 184.0$, and six oxygenated aliphatic carbons $(\delta 82.6,80.1,75.3,72.6$, 71.8 , and 62.9). From these results, compound 5 was deduced to be a flavonoid glycoside bearing a 1,3,4-trisubstituted aromatic B-ring. The structure of 5 was determined to be orientin on the basis of the above evidences, together with a comparison of the above data with those published in the literature (Hwang et al., 1994).

The ${ }^{1} \mathrm{H}$-NMR spectrum of 6 showed the typical pattern of two coupling groups of 1,3,4-trisubstituted benzene rings at $\delta 7.05(1 \mathrm{H}, \mathrm{d}, J=2.0 \mathrm{~Hz}, \mathrm{H}-5$ "), $7.01(1 \mathrm{H}, \mathrm{d}, J=2.0 \mathrm{~Hz}$, $\mathrm{H}^{-5}$ '), $6.92\left(1 \mathrm{H}, \mathrm{dd}, \mathrm{J}=8.0,2.0 \mathrm{~Hz}, \mathrm{H}-9{ }^{\prime \prime}\right), 6.87(1 \mathrm{H}, \mathrm{dd}$, $\left.J=8.0,2.0 \mathrm{~Hz}, \mathrm{H}-9^{\prime}\right), 6.76(1 \mathrm{H}, \mathrm{d}, \mathrm{J}=8.0 \mathrm{~Hz}, \mathrm{H}-8$ ') and 6.75 $\left(1 \mathrm{H}, \mathrm{d}, J=8.0 \mathrm{~Hz}, \mathrm{H}-8^{\prime}\right)$, and two coupling groups of trans coupled olefinic protons at $\delta 7.57(1 \mathrm{H}, \mathrm{d}, J=15.6 \mathrm{~Hz}, \mathrm{H}-3$ "), $7.51\left(1 \mathrm{H}, \mathrm{d}, \mathrm{J}=15.6 \mathrm{~Hz}, \mathrm{H}-3^{\prime}\right), 6.29$ (1H, d, J=15.6 Hz, H-2") and $6.24\left(1 \mathrm{H}, \mathrm{d}, J=15.6 \mathrm{~Hz}, \mathrm{H}-2^{\prime}\right)$. In the ${ }^{13} \mathrm{C}-\mathrm{NMR}$ spectrum of 6 , twenty five carbon signals were observed, which included three carbonyl groups at $\delta 181.8$ (COO), 168.5 (C-1") and 168.4 (C-1'), and six aliphatic carbons at $\delta 75.6$ (C-1), 74.6 (C-4), 70.0 (C-5), 67.6 (C-3), 38.09 (C-2) and 38.05 (C-6). From these results, compound 6 was deduced to be a dihydoxyquinic acid bearing two caffeoyl moieties. The structure of 6 was determined to be 3,4-diO-caffeoylquinic acid on the basis of the above evidences, together with a comparison of the above data with those published in the literature (Timmermann et al., 1983; Kim et al., 1999).

There has been interest in finding various pharmacological active constituents from the fruit of $V$. rotundifolia. Polymethoxyflavonids have been studied the inhibitory ef-

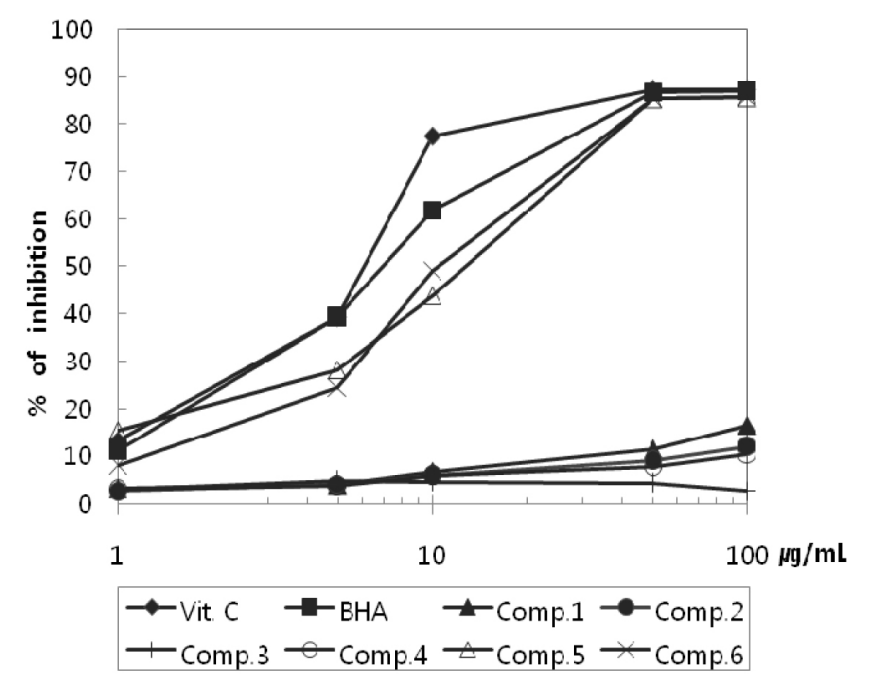

Fig. 3. Radical scavenging effects on DPPH radical of the isolated compounds from the twigs of $V$. rotundifolia. fects on proliferation (You et al., 1998; Ko et al., 2000). It was reported that phenylnaphthalene compounds isolated from this plant showed antibacterial activity against methicillin-resistant Staphylococcus aureus (Kawazoe et al., 2001).

The radical scavenging effects of six compounds obtained from $V$. rotundifolia were shown in Fig. 3. The positive control vitamin $\mathrm{C}$ showed the DPPH radical scavenging effect with the $\mathrm{IC}_{50}$ value of $6.1 \mu \mathrm{g} / \mathrm{ml}$. Compounds 5 and 6 exhibited scavenging activities dose-dependently on $\mathrm{DPPH}$ with $\mathrm{IC}_{50}$ values of 10.8 and $9.9 \mu \mathrm{g} / \mathrm{ml}$, respectively.

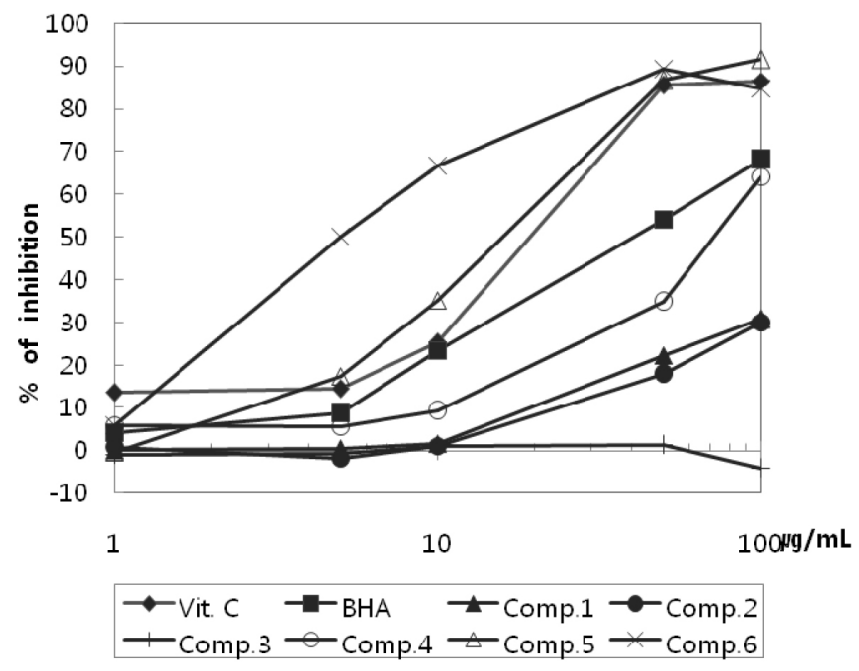

Fig. 4. Riboflavin originated superoxide quenching activities of the isolated compounds from the twigs of $V$. rotundifolia.

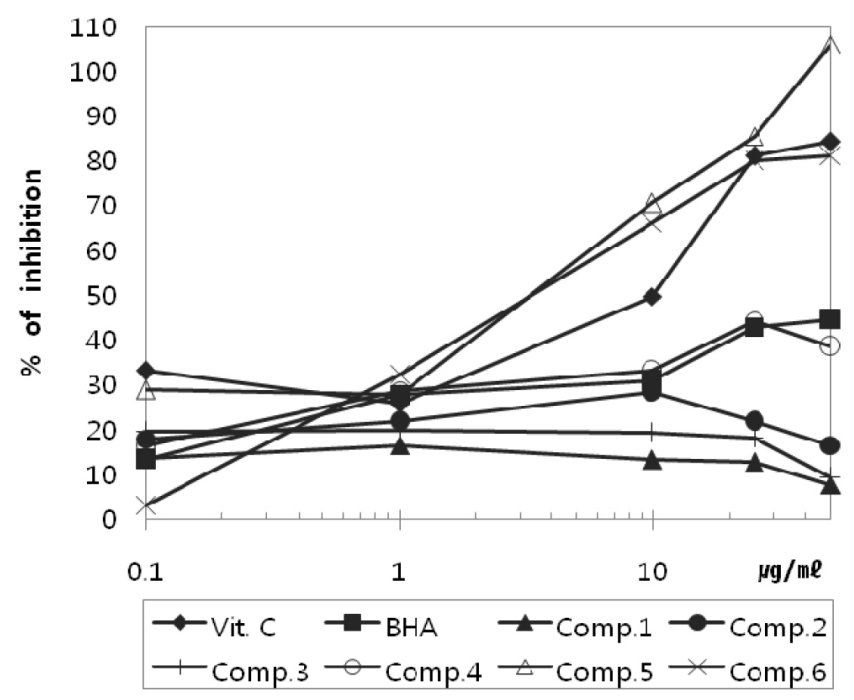

Fig. 5. Xanthine originated superoxide scavenging effects of the isolated compounds from the twigs of $V$. rotundifolia. 
However, compounds 1-4 showed no activities in comparison with reference antioxidants such as ascorbic acid and BHA. Fig. 4 and 5 show the superoxide quenching activities of the isolated compounds 1-6, as measured by the riboflavin-NBT-light and xanthine-NBT-xanthine oxidase systems. Compounds 5 and 6 were found to be potent scavengers of superoxide radical generated in two systems. In riboflavin-NBT-light system, compounds 5 and 6 exhibited the formation of the blue formazan in a dose-dependent manner with $\mathrm{IC}_{50}$ values of 10.3 and $5.1 \mu \mathrm{g} / \mathrm{ml}$, respectively (vitamin $\mathrm{C}$, positive control, $\mathrm{IC}_{50}$ value, 39.7 $\mu \mathrm{g} / \mathrm{ml}$ ) (Fig. 4). In xanthine-NBT-xanthine oxidase system, compounds 5 and 6 also exhibited the formation of the blue formazan in a dose-dependent manner with $\mathrm{IC}_{50}$ values of 3.2 and $3.0 \mu \mathrm{g} / \mathrm{ml}$, respectively (vitamin C, positive control, $\mathrm{IC}_{50}$ value, $9.9 \mu \mathrm{g} / \mathrm{ml}$ ) (Fig. 5). Superoxide quenching activities of compounds 5 and 6 more pronounced than vitamin $\mathrm{C}$, used as a positive control.

Free radicals are highly reactive molecules with an unpaired electron and are produced by radiation or as byproducts of metabolic processes (Devi et al., 2008). Superoxide radical is known to be very harmful to cellular components as a precursor of more reactive oxygen species (Kumaran and Karunakaran, 2006). The results from free radical scavenging systems revealed that the ethyl acetate soluble fraction of the twigs of $V$. rotundifolia, and compounds 5 and 6 had significant antioxidant activities. Therefore compounds 5 and 6 may be useful for the treatment of various oxidative damage.

\section{ACKNOWLEDGMENTS}

This work was supported by Woosuk University (2009).

\section{REFERENCES}

Cheng, W. X., Chen, H. Y., Zhang, Y. P., Qin, X. L. and Gu, K. (2007). Chemical constituents of Vitex quinata. Nat. Prod. Res. Dev. 19, 244-246.

Choi, D. S., Kim, S. J. and Jung, M. Y. (2001). Inhibitory activity of berberine on DNA strand cleavage induced by hydrogen peroxide and cytochrome c. Biosci. Biotechnol. Biochem. 65, 452-455.

Devi, K. R., Suganthy, N., Kesika, P. and Pandian, S. K. (2008). Bioprotective properties of seaweeds: In vitro evaluation of antioxidant activity and antimicrobial cativity against food borne bacteria in relation to polyphenolic content. $B M C$ Complement Altern. Med. 8, 1-11.

El-Naggar, L. J. and Beal, J. L. (1980). Iridoids. A review. J. Nat. Prod. 43, 649-706.

Ginnopolitis, C. N. and Ries, S. K. (1977). Superoxide dismutase. I. Occurrence in higher plants. Plant Physiol. 59, 309-314.
Hwang, Y. J., Lee, S. H., Ryu, S. Y., Ahn, J. W., Kim, E. J, Ro, J. S. and Lee, K. S. (1994). Chemical study on the phenolic compounds from Gleditsia japonica. Kor. J. Pharmacogn. 25, 11-19.

Kawazoe, K., Yutani, A., Tamemoto, K., Yuasa, S., Shibata, H., Higuti, T. and Takaishi, Y. (2001). Phenylnaphthalene compounds from the subterranean part of Vitex rotundifolia and their antibacterial activity against methicillin-resistant Staphylococcus aureus. J. Nat. Prod. 64, 588-591.

Kim, S. Y., Kwon, Y. S. and Kim, C. M. (1999). Chemical constituents from Dipsacus asper. Kor. J. Pharmacogn. 30 420-422.

Kimura, T., But, P. P. H., Guo, J. X. and Sung, C. K. (1996). International collation of traditional and folk medicine. Part I, p. 141, World Scientific, Singapore.

Ko, W. G., Kang, T. H., Lee, S. J., Kim, N. Y., Kim, Y. C., Sohn, D. H. and Lee, B. H. (2000). Polymethoxyflavonoids from Vitex rotundifolia inhibit proliferation by inducing apoptosis in human myeloid leukemia cells. Food Chem. Toxicol. 38, 861-865.

Kumaran, A. and Karunakaran, R. J. (2006). Antioxidant and free radical scavenging activity of and aqueous extract of Coleus aromaticus. Food Chem. 97, 109-114.

Okuyama, E., Fujimori, S., Yamazaki, M. and Deyama, T. (1998). Pharmacologically active components of viticis fructus (Vitex rotundifolia). II. The components having analgesic effects. Chem. Pharm. Bull. 46, 655-662.

Ono, M., Ito, Y., Kubo, S. and Nohara, T. (1997). Two new iridoids from viticis trifoliae fructus (fruit of Vitex rotundifolia L.) Chem. Pharm. Bull. 45, 1094-1096.

Ono, M., Yamamoto, M., Masuoka, C., Ito, Y., Yamashita, M. and Nohara, T. (1999). Diterpenes from the fruits of Vitex rotundifolia. J. Nat. Prod. 62, 1532-1537.

Ono, M., Yamamoto, M., Yanaka, T., Ito, Y. and Nohara, T. (2001). Ten new labdane-type diterpenes from the fruit of Vitex rotundifolia. Chem. Pharm. Bull. 49, 82-86.

Ono, M., Yanaka, T., Yamamoto, M., Ito, Y. and Nohara, T. (2002). New diterpenes and norditerpenes from the fruits of Vitex rotundifolia. J. Nat. Prod. 65, 537-541.

Thuong, P. T., Kang, H. J., Na, M. K., Jin, W. Y., Youn, U. J. and Seong, Y. H. (2007). Anti-oxidant constituents from Sedum takesimense. Phytochemistry 68, 2432-2438.

Timmermann, B. N., Hoffmann, J. H., Jolad, S. D., Schram, K. H., Klench, R. E. and Bates, R. B. (1983). Constituents of Chrysothamanus paniculatus 3: 3,4,5-tricaffeoylquinic acid (A new shikimate prearomatic) and 3,4-, 3,5- and 4,5dicaffeoylquinic acids. J. Nat. Prod. 46, 365-368.

Yoshioka, T., Inokuchi, T., Fujioka, S. and Kimura, Y. (2004). Phenolic compounds and flavonoids as plant growth regulators from fruit and leaf of Vitex rotundifolia. $Z$. Naturforsch. C. 59, 509-514.

Yoshida, T., Mori, K., Hatano, T., Okumura, T., Uehara, L., Komagoe, K., Fujita, Y. and Okuda, T. (1989). Studies on inhibition mechanism of autooxidation by tannins and flavonoids. V. Radical scavenging effects of tannins and related polyphenols on 1,1-diphenyl-2-picrylhydrazyl radical. Chem. Pharm. Bull. 37, 1919-1921.

You, K. M., Son, K. H., Chang, H. W., Kang, S. S. and Kim, H. P. (1998). Vitexicarpin, a flavonoid from the fruits of Vitex rotundifolia, inhibits mouse lymphocyte proliferation and growth of cell lines in vitro. Planta Med. 64, 546-550. 